\title{
Evaluating DSSAT program for simulating wheat yield production with different irrigation and nitrogen applications under Upper Egypt conditions
}

\author{
Gameh M. A. ${ }^{\mathrm{a}}$, Ahmed E. M. ${ }^{\mathrm{a}}$, Dardiry M. R. ${ }^{\mathrm{b}}$, Elmahdy A. M. ${ }^{\mathrm{b}}$ \\ ${ }^{a}$ Soil Science Department, Faculty of Agriculture, Assiut University, Assuit, Egypt \\ ${ }^{b}$ Water Requirements and Field Irrigation Department, Soil, Water and Environment Research Institute, ARC, Giza, Egypt
}

\begin{abstract}
The overall objective of this work was to study the irrigation scheduling effects on the productivity of irrigated wheat in relation to mineral organic nitrogen fertilization, including initial testing of the DSSAT v4.7.0.0 model. In order that, a field experiment was conducted under Upper Egypt conditions in El-Mattana Agricultural Research Station, Luxor governorate, Egypt. The data of irrigation scheduling ((I1) 1.2, (I2) 1.0 and (I3) 0.8 pan evaporation coefficient) and mineral organic nitrogen fertilization program ((F1) $75 \mathrm{~kg} \mathrm{~N}$ fed ${ }^{1}$ as compost, (F2) $75 \% \mathrm{~N}$ as compost $+25 \% \mathrm{~N}$ as mineral, (F3) $50 \% \mathrm{~N}$ as compost $+50 \% \mathrm{~N}$ as mineral (F4) $25 \% \mathrm{~N}$ as compost $+75 \% \mathrm{~N}$ as mineral and (F5) $75 \mathrm{~kg} \mathrm{~N}_{\text {feddan }}{ }^{-1}$ as urea) (feddan $=4200 \mathrm{~m}^{2}=0.420$ hectares $=1.037$ acres) during the two studied seasons 2016/17 and 2017/18, were used for model calibration and validation. Model evaluation results showed a closer relationship between CERES-DSSAT and observed wheat grain yield at both seasons. The values of relative root mean square error (RRMSE), coefficient of residual mass (CRM) and index of agreement (d-stat) were 6.6, 9.6 and 0.90 in the $1^{\text {st }}$ and 3.9, 1.7 and 0.92 in the $2^{\text {nd }}$ season, respectively. So, it could be concluded that the model works well under Upper Egypt condition, thus, studying the impacts of different management and climate change can be applied.
\end{abstract}

Keywords: DSSAT, scheduling, irrigation, evaporation pan.

*Corresponding author: Elmahdy A. M., 


\section{Introduction}

Water is the most important factor in crop production. About $85 \%$ of total water resources in Egypt are consumed by the agricultural sector. Always, water scarcity is the focal point for the most agronomists and on-farm irrigation specialists. The basic work for irrigation water allocation in regional scales is to guarantee the crop yield with limited irrigation water at farm scale. Therefore, irrigation should be accurately timed and quantified, i.e., there must be a robust irrigation scheduling program that ensures minimizing nonproductive soil water by evapotranspiration or drainage losses (Arora and Gajri, 1998). There are many methods and tools used in irrigation scheduling. The World Meteorology Organization (WMO) recommended the Class A evaporation pan for evaporation measurements since it is easy to use and relatively inexpensive (Stanhill, 2002). Agronomists have used the evaporation pan method for irrigation scheduling, and it was proven to save up to $20 \%$ of the applied irrigation water by farmers under Egyptian conditions (Khalil et al., 2009). It is an open pan of water that is subjected to the same climatic conditions with the grown crop, and from which water is evaporated (by wind speed, air temperature, relative humidity and net radiation) as a result of the climatic conditions (Smajstrla et al., 2000). Egypt territory located at the band of dry and semi-arid regions. In general, soils of Egypt characterized by poverty in organic matter content so total nitrogen with less than two percent. However, few studies have been conducted on the use of manures and biofertilizers for agriculture production (FAO, 2005). Continuous application of chemical fertilizers causes soil health problems even if applied in a balanced proportion (Zia et al., 2000). This is mainly due to the quick hydrolysis of chemical fertilizer (Farhad et al., 2013). Also, they pollute our environment as well as kills beneficial soil microorganisms (Noreen and Noreen, 2012). On the other hand, organic matter addition plays a major role in soil fertility: nutrients storage, increasing CEC, improving soil structural stability, fauna stimulation and microbial \& enzymatic activities (Feller, 1995). Also, it improves soil physical properties and increasing the soil water holding capacity (Chandra, 2005). Integrated nutrient management is essential for proper plant growth, water use, soil and land management, which will be critical for the sustaining agriculture productivity over the long term. The overall strategy for increasing crop yields and sustain their high production must include an integrated approach of soil nutrients. An integrated approach recognizes that soils are the storehouse of most essential nutrients for plant (Shah et al., 2010). Concerning this vision, many scientists like Shah and Ahmed (2006), Shah et al. (2010) and Koushal et al. (2011) recommended that applying $\mathrm{N}$ as a mineral and organic form in 75:25 or 50:50 ratios of basis $\mathrm{N}$ would be profitable for wheat productivity and sustainable soil fertility. Crop models allow researchers and agricultural investors to get well-informed research and crop management decisions (Jones et al., 2003). The DSSAT is a computer program consists of modules for the 
growth and development of different crop types, soil water balance, soil organic matter \& nitrogen, crop residues, soil phosphorous, soil $\mathrm{pH}$, soil erosion, and crop management. The crop 'Manager' module allows the user to interact directly with program variables that affect field management operations (sowing, applying fertilizer, irrigation, harvesting) and also to track the values of system variables as well as calculate additional derived values (Jones, 2013). CERESWheat is one of the various DSSAT program windows. Simulates crop development, growth and partitioning assimilates various plant parts as a function of environmental factors such as soils, weather and crop characteristics. Phenological development and growth of a crop are specified in DSSAT by cultivar-specific genetic coefficients (Hoogenboom et al., 2004). The DSSAT has not yet applied under Upper Egypt condition, and to recommend it for the public use, a deliberated calibration and validation are required, then comparing model simulations with close data observations from actual experiment yields. After that, a more detailed analysis of crop performance can be conducted for different management (soil, plant, irrigation and fertilizer strategies) and climate change to determine the most promising and least risky practice. So, in this study, Cropping System Model CERES-Wheat of DSSAT 4.7 software was evaluated using irrigation and nitrogen practices that attain the highest wheat yield under the implemented experimental conditions of Upper Egypt.

\section{Materials and Methods}

A field experiment was conducted at ElMatteana Agricultural Research Station, Luxor governorate, Upper Egypt during winter wheat growing seasons of 2016/17 and 2017/18.

\subsection{Climatic characteristics prevailing}

Monthly means of maximum, minimum and average temperature $\left({ }^{\circ} \mathrm{C}\right)$, relative humidity $(\%)$, wind speed $(\mathrm{m} / \mathrm{sec})$, rainfall $(\mathrm{mm})$ and possible sunshine duration (hours/day) for the experimental site during two growing seasons of 2016/17 and 2017/18 are presented in Table (1).

Table (1): Meteorological data for El-Mattana Agricultural Research Station, Luxor, Egypt during wheat growing seasons of 2016/17 and 2017/18.

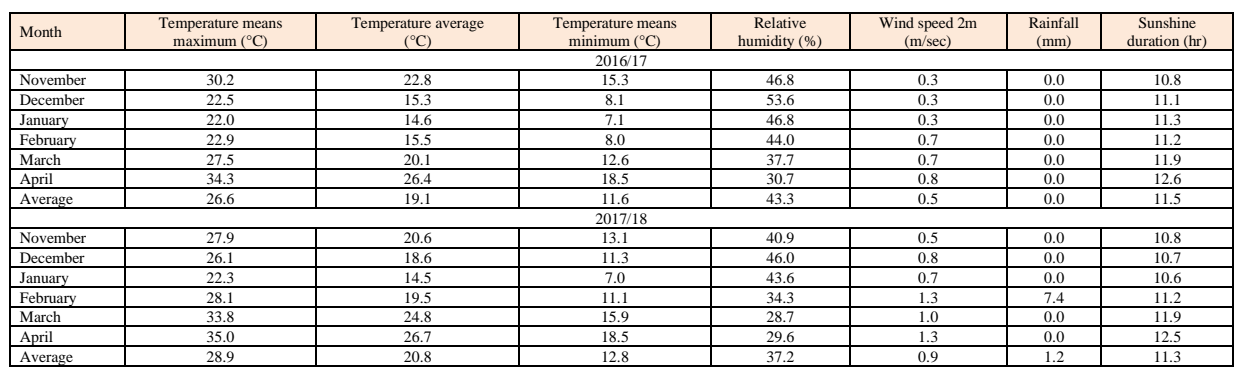

Source: Central Laboratory for Agricultural Climate, Giza Egypt. 


\subsection{Soil properties of the experimental site}

Physical and chemical properties of the experimental field are presented in Table (2).

\subsection{The biological experiment}

Wheat seeds MISR2 (Triticum aestivum $L$.) were sown on $27^{\text {th }}$ of November 2016 and repeated in the same date in 2017.
The experimental design was split plot design with 3 irrigation regimes and $5 \mathrm{~N}$ fertilization schedule in 3 replications. The main plot area represented irrigation scheduling. Each main plot was divided into 5 sub-plots that received $\mathrm{N}$ fertilizer regimes. The total number of the experimental plots was 45 plots Table (3). Chemical and physical analyses of added compost are presented in Table (4).

Table (2): Physical and chemical properties of the experimental field.

\begin{tabular}{|l|c|c|l|}
\hline \multirow{2}{*}{ Properties } & \multicolumn{2}{|c|}{ Value } & \multirow{2}{*}{ Method employed } \\
\cline { 2 - 4 } & $2016 / 17$ & $2017 / 18$ & \\
\hline Soil texture & \multicolumn{2}{|c|}{ Clay loam } & International pipette method (Piper, 1966). \\
\hline Soil pH & 7.75 & 7.79 & $(1: 2.5$, soil: water) pH meter instrument (Brower and Zar, 1984) \\
\hline $\mathrm{EC}\left(\mathrm{dS} / \mathrm{m}\right.$ at $\left.25^{\circ} \mathrm{C}\right)$ & 1.3 & 1.28 & $(1: 5$, soil: water) electrical conductivity meter (Rowell, 1994) \\
\hline $\mathrm{CaCO}_{3}(\%)$ & 3.5 & 4.1 & $\mathrm{Collins}^{+}$Calorimeter $(\mathrm{FAO}$, Soil Bulletin 38/2, 1980) \\
\hline Available $\mathrm{N}(\mathrm{ppm})$ & 57 & 55 & $\left(\mathrm{NH}_{4}{ }^{+}\right)+\left(\mathrm{NO}_{3}^{-}\right)(\mathrm{FAO}, 2008)$ \\
\hline Available $\mathrm{P}(\mathrm{ppm})$ & 10.4 & 11 & $0.5 \mathrm{M} \mathrm{Na} \mathrm{HCO3} \mathrm{at} \mathrm{pH} \mathrm{8.2} \mathrm{(FAO,} \mathrm{2008)}$ \\
\hline Available $\mathrm{K}(\mathrm{ppm})$ & 282 & 278 & Photometric method (FAO, 2008) \\
\hline
\end{tabular}

Source: Central Laboratory for Agricultural Climate, Giza Egypt.

Table (3): The studied factors and their treatments.

\begin{tabular}{|l|l|c|}
\hline Factor & Treatment & Legend \\
\hline \multirow{3}{*}{$\begin{array}{l}\text { Irrigation } \\
\text { scheduling }\end{array}$} & 1.2 pan evaporation coefficient & $\mathrm{I} 1$ \\
\cline { 2 - 3 } & 1.0 pan evaporation coefficient & $\mathrm{I} 2$ \\
\cline { 2 - 3 } & 0.8 pan evaporation coefficient & $\mathrm{I} 3$ \\
\hline \multirow{5}{*}{ Fertilization levels } & $75 \mathrm{~kg} \mathrm{~N}$ fed $^{-1}$ as compost $(100 \%$ organic) & $\mathrm{F} 1$ \\
\cline { 2 - 3 } & $75 \% \mathrm{~N}$ as compost $+25 \% \mathrm{~N}$ as mineral & $\mathrm{F} 2$ \\
\cline { 2 - 3 } & $50 \% \mathrm{~N}^{2}$ as compost $+50 \% \mathrm{~N}$ as mineral & $\mathrm{F} 3$ \\
\cline { 2 - 3 } & $25 \% \mathrm{~N}$ as compost $+75 \% \mathrm{~N}$ as mineral & $\mathrm{F} 4$ \\
\cline { 2 - 3 } & $75 \mathrm{~kg} \mathrm{~N}$ fed $^{-1}$ as urea $(100 \%$ mineral) & $\mathrm{F} 5$ \\
\hline \multirow{2}{*}{ Treatments } & $\begin{array}{l}\mathrm{I} 1 \mathrm{~F} 1, \mathrm{I} 1 \mathrm{~F} 2, \mathrm{I} 1 \mathrm{~F} 3, \mathrm{I} 1 \mathrm{~F} 4 \text { and I1F5), (I2F1, I2F2, I2F3, I2F4 and I2F5) and (I3F1, I3F2, I3F3, I3F4 } \\
\text { and I3F5) }\end{array}$ & \\
\hline
\end{tabular}

Table (4): Chemical and physical analysis of added compost.

\begin{tabular}{|c|c|c|c|}
\hline Properties & $2016 / 17$ & $2017 / 18$ & Method employed \\
\hline Weight $/ \mathrm{M}^{3}(\mathrm{Kg})$ & 520 & 500 & \\
\hline Moist content (\%) & 30 & 27 & Dried at $70^{\circ} \mathrm{C}$ to constant weights (Page et al., 1982 ) \\
\hline $\mathrm{PH}(1: 10)$ & 8.5 & 8.7 & pH meter instrument (Brower and Zar, 1984) \\
\hline $\mathrm{EC}(1: 10) \mathrm{dSm}^{-1}$ & 4.45 & 4.48 & Electrical conductivity meter (Rowell, 1994) \\
\hline $\mathrm{TN}(\%)$ & 1.5 & 1.4 & Microkjeldahl method (FAO, 2008). \\
\hline Soluble $\mathrm{N}\left(\mathrm{NH}_{4}^{+}\right)(\mathrm{mg} / \mathrm{kg})$ & 861 & 855 & FAO (2008) \\
\hline Soluble $\mathrm{N}\left(\mathrm{NO}^{-}\right)(\mathrm{mg} / \mathrm{kg})$ & 65 & 63 & FAO (2008) \\
\hline Organic Matter (\%) & 41.65 & 41.0 & Page et al. (1982) \\
\hline Organic Carbon (\%) & 24.16 & 24.11 & $\mathrm{C}$ content $\%=\mathrm{O} \mathrm{M} \% \div 1.7241$ (Nelson and Sommers, 1996 ) \\
\hline C/N Ratio & $16: 1$ & $15: 1$ & $\mathrm{C}$ content $\% / \mathrm{N}$ content $\%$ \\
\hline $\mathrm{TP}(\%)$ & 1.65 & 1.68 & Spectrophotometrically (FAO, 2008) \\
\hline TK $(\%)$ & 1.41 & 1.43 & Flame photometry $(\mathrm{FAO}, 2008)$ \\
\hline
\end{tabular}




\subsection{Measured data}

Growth parameters were measured at the field as shown in Table (5).

\subsection{Statistical analysis}

The obtained data were analyzed using the statistical package MSTAT-C (Nissen, 1989). Mean values were compared for each other using the Least Significant Differences (LSD) at the probability level of 0.05 where the effects of the treatments were significant at $5 \%$ level of probability.

Table (5): Wheat growth parameters and its yield.

\begin{tabular}{|c|l|l|l|}
\hline Sl. No. & Observations recorded & Periodicity & \multicolumn{2}{|c|}{ Yield attributing characters } \\
\hline 2.4 .1 & \multicolumn{3}{|c|}{ Methods followed } \\
\hline & Grain yield & At harvest & $\begin{array}{l}\text { After threshing, the grains of each plot were weighed, and the } \\
\text { average grain yield (ton/feddan) was calculated at 15.5\% moisture. }\end{array}$ \\
\hline & Biological yield & At harvest & Weighting all the dry plants at each plot before shelling. \\
\hline & Straw yield (ton/feddan) & At harvest & $\begin{array}{l}\text { By subtracting from biological yield (ton/feddan) the grain weight } \\
\text { (ton/feddan) for each plot. }\end{array}$ \\
\hline 2.4 .2 & \multicolumn{3}{|c|}{ Yield components } \\
\hline & $\begin{array}{l}\text { The average number of } \\
\text { grains/spike }\end{array}$ & At harvest & \\
\hline & $\begin{array}{l}\text { The average weight of } \\
1000 \text { - grains (gm) }\end{array}$ & At harvest & \\
\hline
\end{tabular}

\subsection{DSSAT modeling}

\subsubsection{Model inputs}

The DSSAT model requires daily weather data, including the maximum and minimum daily air temperature, daily precipitation, and solar radiation. Also, it requires soil data including general site, soil surface information and soil profile characteristics (physical, chemical and morphological properties). Also, it requires detailed crop management information including initial soil water content, soil inorganic N, crop cultivar, plant density, sowing date, and fertilization (Hoogenboom et al., 2012).

\subsubsection{Model calibration}

The cultivar coefficients must be calibrated under the normal optimum conditions. So, CERES-Wheat model was calibrated for the grown field that determinate wheat developing using three irrigation regimes and five integrated fertilization programs under Upper Egypt conditions. This calibration was achieved by comparing the input data of the first season, with the simulated values comes out from the model.

\subsubsection{Model validation}

Observed experimental data of wheat in the second season were used to validate the performance of the CERES-Wheat model.

\subsubsection{Model evaluation}

Different statistical tools were used to evaluate the performance of the model in predicting various parameters. Relative 
root mean square error (RRMSE) and coefficient of residual mass (CRM) were used to evaluate the DSSAT model. The CERES-Wheat model was evaluated according to the following statistical parameters.

\subsubsection{Relative root mean square error}

Both the observed and simulated data by studied models were compared using the relative root mean square error (RRMSE) as described by Loague and Green (1991). The simulation is considered excellent with RRMSE $<10 \%$, good if $10-20 \%$, fair if $20-30 \%$, poor if $>30 \%$ (Jamieson et al., 1991). This parameter was calculated as follows:

$$
\text { RRMSE }=\sqrt{\frac{1}{n} \sum_{i=1}^{N}\left(P_{i}-O_{i}\right)^{2}} \times \frac{100}{\bar{O}}
$$

Where: $n$ is the number of observations, $P_{i}$ and $O_{i}$ are predicted and observed values respectively, $\bar{O}$ is the observed mean value.

\subsubsection{Coefficient of residual mass}

The coefficient of residual mass (CRM) was used to measure the tendency of the model to overestimate or underestimate the measured values. The CRM is defined by the following equation:

$$
C R M=100 \times \frac{\left[\sum O_{i}-\sum S_{i}\right]}{\sum O_{i}}
$$

Where, $O_{i}=$ observed variable, $S_{i}=$ simulated variable.

A negative CRM value indicates a tendency of the model towards overestimation (Xevi et al., 1996). The simulated data were compared with experimental data and agreement has been checked by CRM and also by the percentage difference between these two values. The permissible or tolerance percentage error is up to 20 percent. If the difference between simulated and observed values is/are above 20 percent than the model performance, it will report as poor and if the difference lies within 20 percent range, it will report good or close agreement.

\subsubsection{The index of agreement}

The index of agreement (d) was estimated as shown in the following equation:

$$
d=1-\left[\frac{\sum_{i=1}^{n}\left(S_{i}-O_{b}\right)^{2}}{\sum_{i=1}^{n}\left(\left|S_{i}\right|+\left|O_{b}\right|\right)^{2}}\right]
$$

Where $\mathrm{n}$ is the number of observations, $S_{i}$ the predicted observation, $O_{b}$ is a measured observation, $S_{i}=S_{i}-\mathrm{M}$ and $\mathrm{Ob}=O_{b}-\mathrm{M}(\mathrm{M}$ is the mean of the observed variable). So, if the d-statistic value is closer to one, then there is good agreement between the two variables that are being compared and vice versa. So, it is very important that if value varies from value of one then there will be weak agreement of the variable that we are being compared with each other. 


\section{Results and Discussion}

\subsection{Wheat yield and its components}

\subsubsection{Grains number /spike}

The grains number /spike showed significant response to irrigation treatments during both seasons as shown in Table (6) and Figure (1). Irrigation scheduling at I1 and I2 significantly increased grains number /spike by $8.3 \%$ compared to irrigation scheduling at I 3 in the $1^{\text {st }}$ season, also irrigation scheduling at I1 and I2 and significantly increased grains number /spike by 26.3 and $28.5 \%$ in the $2^{\text {nd }}$ season, compared to irrigation scheduling at $\mathrm{I} 3$, respectively.

Table (6): Wheat yield and its components as affected by irrigation scheduling, and $\mathrm{N}$ fertilization regimes in both seasons.

\begin{tabular}{|c|c|c|c|c|c|c|c|c|c|}
\hline \multirow{2}{*}{\multicolumn{2}{|c|}{ Treatments }} & \multicolumn{2}{|c|}{ No of grains/spike } & \multicolumn{2}{|c|}{ 1000-grains (g) } & \multicolumn{2}{|c|}{ Grain yield (ton/feddan) } & \multicolumn{2}{|c|}{ Straw yield (ton/feddan) } \\
\hline & & $2016 / 17$ & $2017 / 18$ & $2016 / 17$ & $2017 / 18$ & $2016 / 17$ & $2017 / 18$ & $2016 / 17$ & $2017 / 18$ \\
\hline \multirow{5}{*}{ I1 } & F1 & 60 & 56 & 43.7 & 43.5 & 2.27 & 1.93 & 7.13 & 6.05 \\
\hline & F2 & 53 & 58 & 48.9 & 48.3 & 2.74 & 2.30 & 7.10 & 6.37 \\
\hline & F3 & 55 & 59 & 48.9 & 49.2 & 3.26 & 2.40 & 7.98 & 6.40 \\
\hline & F4 & 62 & 59 & 49.6 & 47.5 & 3.46 & 2.57 & 8.03 & 7.00 \\
\hline & F5 & 64 & 50 & 47.7 & 47.0 & 3.32 & 2.47 & 9.81 & 6.50 \\
\hline \multirow{5}{*}{$\mathrm{I} 2$} & F1 & 55 & 54 & 43.5 & 47.1 & 2.32 & 1.89 & 7.10 & 5.32 \\
\hline & F2 & 58 & 50 & 42.3 & 44.4 & 2.77 & 2.28 & 7.37 & 5.67 \\
\hline & F3 & 60 & 63 & 44.2 & 45.0 & 3.32 & 2.37 & 8.10 & 6.38 \\
\hline & F4 & 60 & 61 & 50.6 & 45.0 & 3.53 & 2.40 & 8.73 & 6.21 \\
\hline & F5 & 60 & 58 & 49.7 & 45.6 & 3.32 & 2.30 & 8.67 & 6.84 \\
\hline \multirow{5}{*}{$\mathrm{I} 3$} & F1 & 52 & 46 & 43.7 & 44.7 & 2.21 & 1.77 & 7.13 & 5.04 \\
\hline & F2 & 53 & 43 & 45.5 & 43.3 & 2.59 & 2.13 & 7.53 & 5.25 \\
\hline & F3 & 53 & 45 & 48.6 & 42.9 & 2.94 & 2.27 & 7.87 & 6.25 \\
\hline & F4 & 55 & 43 & 45.2 & 43.8 & 3.35 & 2.30 & 7.93 & 6.12 \\
\hline & F5 & 58 & 46 & 46.4 & 43.5 & 3.21 & 2.17 & 8.13 & 6.08 \\
\hline \multicolumn{2}{|c|}{ Average } & 57 & 53 & 46.6 & 45.4 & 2.97 & 2.24 & 7.91 & 6.10 \\
\hline \multirow{3}{*}{ 会㓠 } & I & 4.6 & 8 & N.S. & 2.47 & 0.09 & 0.14 & 0.31 & 0.54 \\
\hline & $\mathrm{F}$ & N.S. & N.S. & 2.71 & N.S. & 0.17 & 0.15 & 0.40 & 0.43 \\
\hline & $\mathrm{IxF}$ & N.S. & N.S. & N.S. & N.S. & N.S. & N.S. & 0.69 & N.S. \\
\hline
\end{tabular}

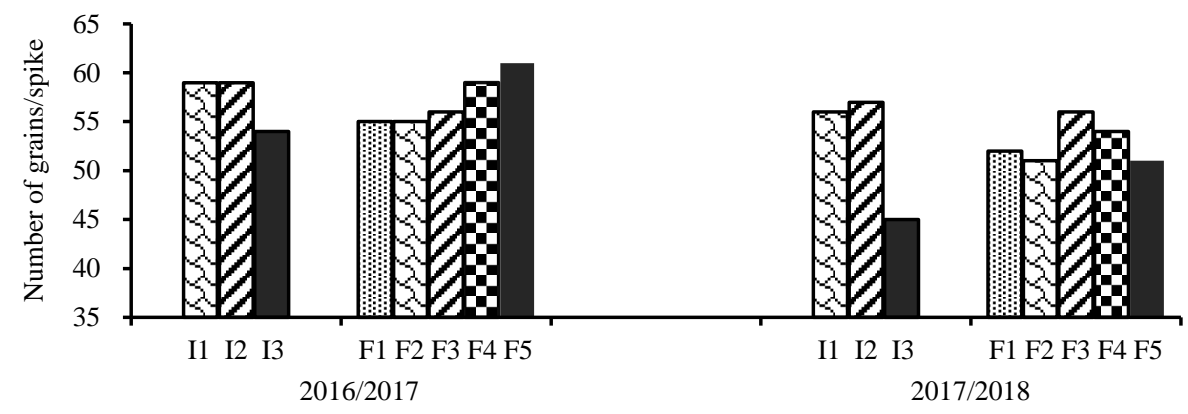

Figure (1): Grains number /spike as affected by irrigation scheduling and $\mathrm{N}$ fertilization regimes in 2016/17 and 2017/18 seasons. 
These results indicated that the maximum grains number /spike were obtained through irrigation scheduling at 1.2 and 1.0 values of accumulated pan evaporation. This might be attributed to the positive effect of more available moisture. The reproductive growth stage is more sensitive to drought than the vegetative stage, resulting in fewer flowers, poor pod or fruit set, which decreases seed numbers (Pushpavalli et al., 2014), these results are in agreement with those of Youssef et al. (2013) and Rao et al. (2013). Application of organic and inorganic amendments exerted insignificant variation in wheat grains number /spike during both seasons. The data in figure (5) and table (7) indicated that the use of F5 treatment increased grains number /spike by 9.4, 10.6, 7.7 and $3.0 \%$ in the $1^{\text {st }}$ season compared to $\mathrm{F} 1, \quad \mathrm{~F} 2, \quad \mathrm{~F} 3$ and $\mathrm{F} 4$ treatments, respectively. While F3 treatment increased grains number /spike by 7.6, $10.0,2.5$ and $8.9 \%$ in the $2^{\text {nd }}$ season compared to F1, F2, F4 and F5 treatments, respectively. These results are similar to those obtained by Rehman et al. (2008).

\subsubsection{Weight of 1000-grains $(\mathrm{g})$}

The 1000-grains weight in Table (6) and Figure (2) showed insignificant increase under irrigation scheduling at I1 and I2 by $4.1 \%$ and $0.38 \%$ in the $1^{\text {st }}$ season, and significant increase by $7.9 \%$ and $4.1 \%$ in the $2^{\text {nd }}$ season compared to irrigation scheduling at I3, respectively. It is worthy to mention that the maximum 1000-grains weight of the two seasons was obtained through irrigation scheduling at 1.2 values of accumulated pan evaporation.

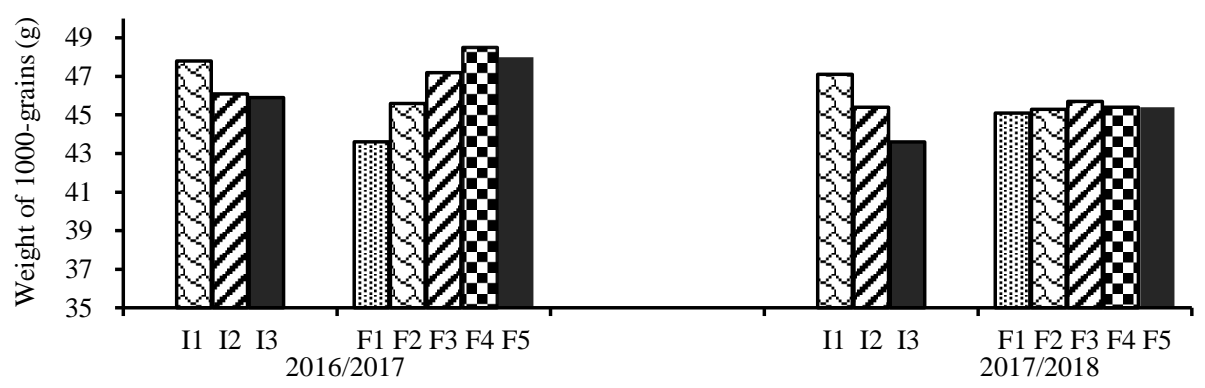

Figure (2): 1000 grains weight as affected by irrigation scheduling and $\mathrm{N}$ fertilization regimes in 2016/17 and 2017/18 seasons.

This might be attributed to the positive effect of more available moisture at the grain filling stage on increasing 1000 - grain weight (Sehgal et al., 2018). These results are in agreement with those of Namait Allah et al. (2008), Rao et al. 
(2013) and Youssef et al. (2013). The use of organic and inorganic amendments together exerted variation in 1000-grains weight as cleared in table (7) and figure (6). Application of F4 treatment led to a significant increase in 1000-grains weight by $11.0,6.3,2.6$ and $\% 1$ in 2016/17 season compared to F1, F2, F3and F5 treatments, respectively. While F3 treatment increased insignificantly the 1000 -grains weight by $1.3,0.79,0.61$ and $0.76 \%$ in the $2^{\text {nd }}$ season, compared to F1, F2, F4 and F5 treatments, respectively. The large accumulation of proteins and other reserved food in the seed that caused increases in 1000 grain weight may be due to the nutrients availability especially nitrogen from the applied fertilizers, where $\mathrm{N}$ portion released from organic sources and the other from mineral source. The mineral $\mathrm{N}$ source fulfills the $\mathrm{N}$ requirements at early growth stages while farmyard manure facilitated crop with maximum nutrients in later stages. In combination (mineral + organic) nourished the crop in initial stages as well as in later stages (Shah et al., 2010). These results are in accordance with those of Jala-Abadi et al. (2012), Mohamed and Abdel-Rahman (2015), and Ahmed et al. (2017).

\subsubsection{Grain yield (ton/feddan)}

The mean wheat grain yields were 2.97 and $2.24 \mathrm{t} \mathrm{fed}^{-1}$ in the $1^{\text {st }}$ and $2^{\text {nd }}$ season, respectively (Table 6 and Figure 3). The yield production in the first season increased by $33 \%$ compared to that of the $2^{\text {nd }}$ one. This might be attributed to the cooler weather conditions in the $1^{\text {st }}$ season as it shown in Table (1). The reduction in the productivity in the second season is attributed to higher temperature, which could have negative impacts as heat stress on pollen fertility and grain abortion (Calderini et al., 1999). High temperatures also accelerate crop development, and the duration of crop growth phases decreases, producing negative effects on final grain weight and yield in field crops (Sánchez et al., 2013), which resulting in fewer spikelets per spike and grains per spikelet in the second season. Regarding irrigation treatments, the wheat grain yield (ton feddan $^{-1}$ ) at I1 and I2 were significantly increased by 5.2 and $6.7 \%$ in the $1^{\text {st }}$ season, and by 9.8 and $5.7 \%$ in the $2^{\text {nd }}$ season compared to irrigation scheduling at I3, respectively. From the abovementioned results, it could be concluded that maximum grain yield (ton/fed.) values of both seasons were obtained through irrigation scheduling at 1.2 and 1.0 values of accumulated pan evaporation. These results are in agreement with those of El-Marsafawy (2000), Rayanet al. (2000) and Rao et al. (2013). The integrated fertilization clearly enhanced wheat grain yield since F4 treatment led to a significant increase in wheat grain by 52.1, 27.5, 8.5 and $4.9 \%$ in the $1^{\text {st }}$ season, and by $30,8.4,3.3$ and $4.8 \%$ in the $2^{\text {nd }}$ season compared to F1, F2, F3 and F5 treatments, respectively. These results are in harmony with those obtained by Shah 
and Ahmad (2006), Shah et al. (2010) and Gomaa et al. (2015). The results indicated that the maximum grain yield of both seasons was obtained through irrigation scheduling at I1 and I2 of accumulated pan evaporation and F4 fertilization regime $(75 \%$ mineral and $25 \%$ organic). This increase is run the same trend of increasing grains number /spike and 1000-grain weight.

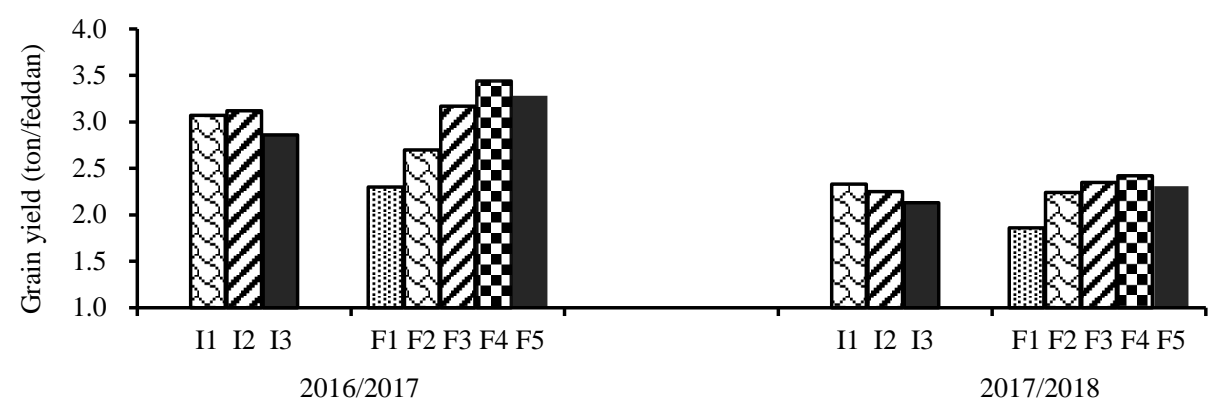

Figure (3): Grain yield (ton/feddan) as affected by irrigation scheduling, and $\mathrm{N}$ fertilization regimes in the two studied seasons.

\subsubsection{Straw yield (ton/feddan)}

The straw yield in Figure (4) and Table (6) showed a was significant increase at I1 and I 2 by 3.8 and $3.6 \%$ in the $1^{\text {st }}$ season, and by 12.5 and $5.8 \%$ in the $2^{\text {nd }}$ season compared to irrigation scheduling at I3, respectively. The results indicated that the maximum straw yield values of both seasons were obtained through irrigation scheduling at 1.2 values of accumulated pan evaporation. This increase could be attributed to plant height and leaf area increases. These results are in agreement with those of Namait Allah et al. (2008), El-Sayed (2012), and Youssef et al. (2013).
Regarding fertilization regimes, F5 treatment led to a significant increase in straw yield by 24.6, 21.0, 11.2and \%7.8 in the $1^{\text {st }}$ season and by $18.2,12.3,2.0$ and $0.48 \%$ in the $2^{\text {nd }}$ one compared to $\mathrm{F} 1$, F2, F3 and F4 treatments, respectively (table 7 and figure 8). Singh and Agarwal (2001) reported that the application of mineral $\mathrm{N}$ alone or with organic $\mathrm{N}$ increased plant growth significantly due to the stronger role of $\mathrm{N}$ in cell division; cell expansion and enlargement which ultimately affect the vegetative growth of wheat plant particularly plant height. These results are in harmony with Halepyati (2001), and Subhanet al. (2017). 


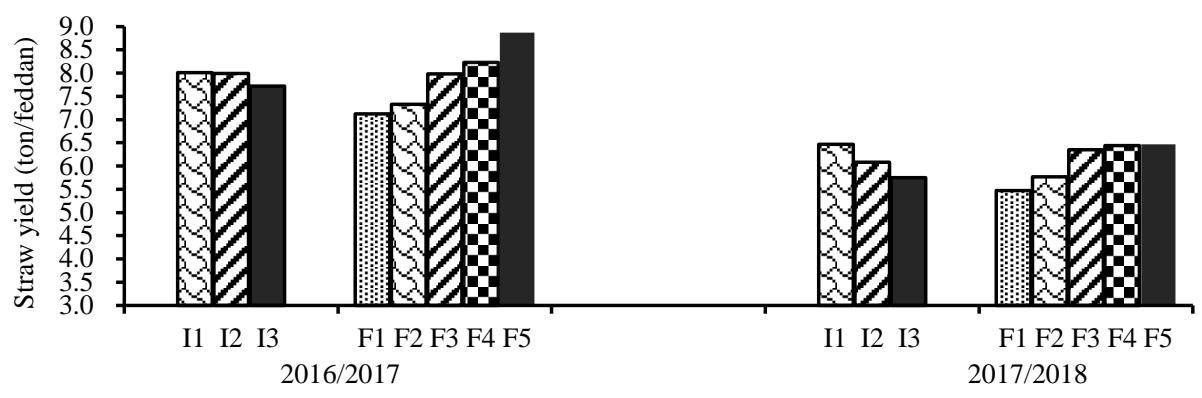

Figure (4): Straw yield (ton/feddan) as affected by irrigation scheduling, and N fertilization regimes in the two studied seasons.

\subsection{Wheat modeling}

\subsubsection{Calibration of the CERES-Wheat model}

Wheat growth and yield data of the 2016/17 growing season were used to calibrate the DSSAT model and to determine the genetic coefficients of Misr2 cultivar under Upper Egypt condition. Table (7) showed the definition and the calibrated value of Misr2 wheat cultivar. These genetic coefficients explain how the life cycle of the cultivar responds to its environment.

Table (7): Genetic coefficients for wheat variety Misr 2.

\begin{tabular}{|c|c|c|c|c|}
\hline Coefficient & Definition & Minimum & Maximum & Calibrated values \\
\hline P1V & $\begin{array}{l}\text { Days at optimum vernalizing temperature required to complete } \\
\text { vernalization. }\end{array}$ & 0 & 60 & 1.0 \\
\hline P1D & $\begin{array}{l}\text { Percentage reduction in development rate in a photoperiod } 10 \\
\text { hour shorter than the threshold relative to that at the threshold }\end{array}$ & 0 & 200 & 90 \\
\hline P5 & Grain filling (excluding lag) phase duration $\left({ }^{\circ} \mathrm{C} . \mathrm{d}\right)$. & 100 & 999 & 650 \\
\hline G1 & Kernel number per unit canopy weight at anthesis $\left(\# \mathrm{~g}^{-1}\right)$. & 10 & 50 & 45 \\
\hline G2 & Standard kernel size under optimum conditions (mg). & 10 & 80 & 80 \\
\hline G3 & $\begin{array}{l}\text { Standard, non-stressed dry weight (total, including grain) of a } \\
\text { single tiller at maturity (g). }\end{array}$ & 0.5 & 8 & 8 \\
\hline PHINT & Interval between successive leaf tip appearances $\left({ }^{\circ} \mathrm{C} . \mathrm{d}\right)$ & 30 & 150 & 150 \\
\hline
\end{tabular}

The minimum crop parameters required for cultivar coefficients calculations include dates of emergence, anthesis, and physiological maturity, maximum leaf area index, grains number per square meter, grains number per spike, grain and biological yield and harvest index. The default wheat cultivar CI0001 Yecora_Rojo (in WHCER045.CULfile) was selected for cultivar calibration. The calibration was made using a 'Trial and Error' method by setting up a small change (i.e., $\pm 5 \%$ ) of each parameter until the desired level of agreement between simulated and observed values was reached. The average of simulated grain yield was $2689 \mathrm{~kg} /$ feddan and the observed grain yield average was 2974 $\mathrm{kg} /$ feddan (Figure 5). The highest grain yield $(3530 \mathrm{~kg} /$ feddan $)$ was recorded 
under 1.0 evaporation pan coefficient and received $75 \%$ organic and $25 \%$ mineral $\mathrm{N}$ (I2F4 treatment), and it was 3413 $\mathrm{kg} /$ feddan for the observed or simulated yield. Also, the lowest grain yield was recorded under 0.8 evaporation pan coefficient and received $100 \%$ organic $\mathrm{N}$ (I3F1 treatment) and it was 2210 $\mathrm{kg} /$ feddan and $1688 \mathrm{~kg} /$ feddan for observed and simulated yield, respectively.

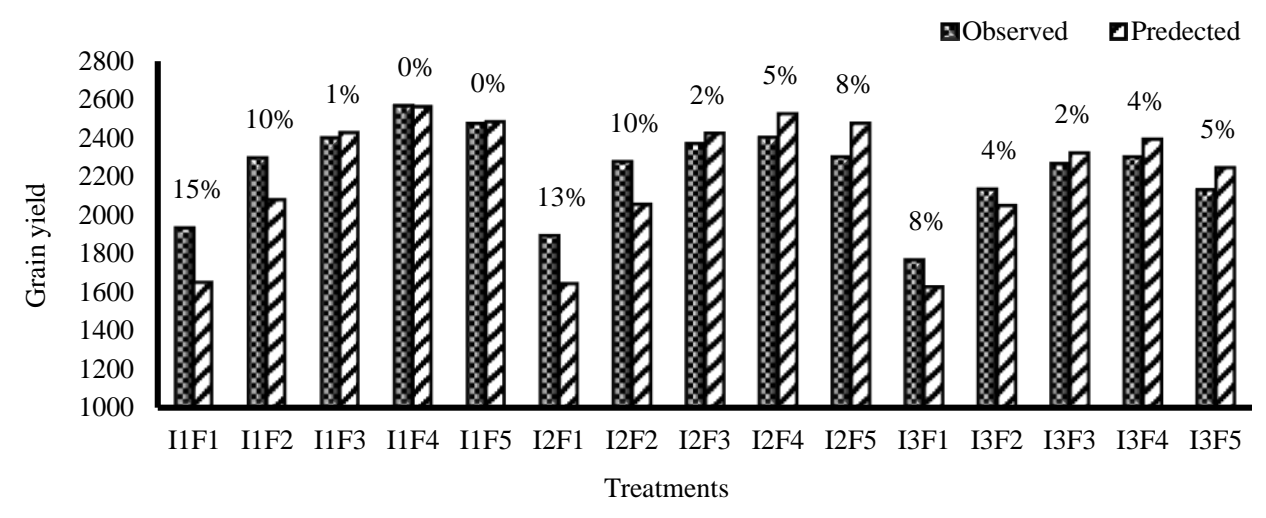

Figure (5): The observed and predicted wheat grain yield in 2016/2017 season.

\subsubsection{Validation of CERES-Wheat model}

The measured experimental data of wheat in the second season (2017/2018) were used to validate the performance of CERES-Wheat model. The observed and predicted grain yield data in 2017/2018 by CERES-Wheat are presented in Figure (6). The average of simulated grain yield was $2196 \mathrm{~kg} / \mathrm{feddan}$, and the observed grain yield average was 2234 $\mathrm{kg} /$ feddan. The highest grain yield (2567 $\mathrm{kg} /$ feddan) was recorded under 1.2 evaporation pan coefficient and received $75 \%$ organic and $25 \%$ mineral $\mathrm{N}$ (I1F4 treatment), and it was $2560 \mathrm{~kg} /$ feddan for observed or simulated yield. While the lowest grain yield $(1767 \mathrm{~kg} /$ feddan) was recorded under 0.8 evaporation pan coefficient and received $100 \%$ organic $\mathrm{N}$ (I3F1 treatment) and it was $1625 \mathrm{~kg} /$ feddan for observed and simulated yield. 


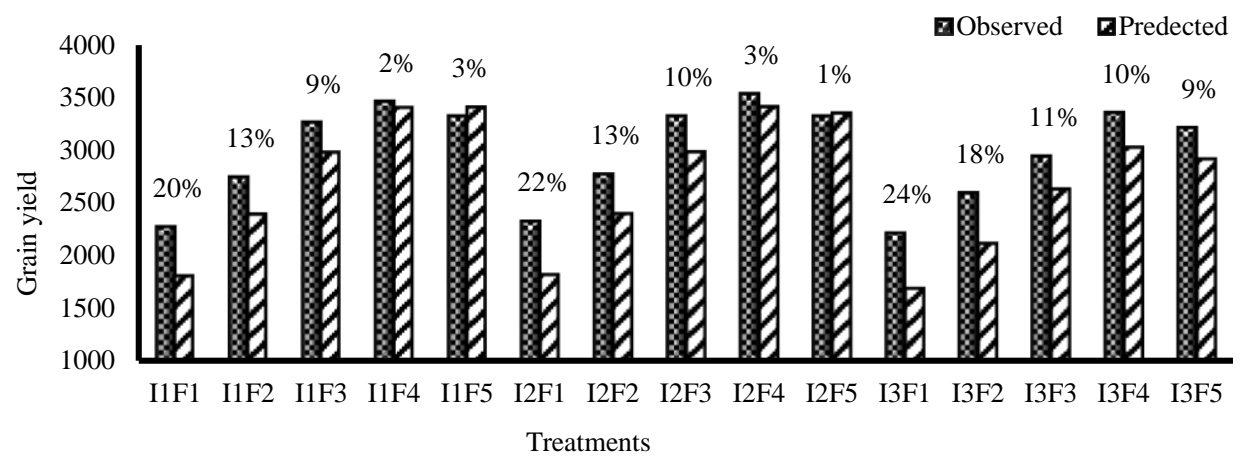

Figure (6): The observed and predicted wheat grain yield in 2017/2018 season.

\subsubsection{Evaluating CEARS-Wheat model using data of the first growing season}

Predicted and observed wheat grain yield for both seasons, RRMSE, CRM and dState evaluation among them are presented in Table (8). Generally, DSSAT showed a reasonable ability for wheat grain yield prediction. The RRMSE showed an excellent interaction between predicted and observed data, and its value was 6.6 for grain yield. The coefficient of residual mass (CRM) and the Index of agreement (d) indicated a good agreement for grain yield, and its values was 9.6 and 0.90 , respectively. In the second season, DSSAT confirmed the similar coincidence of the first season, RRMSE indicated an excellent agreement, and its value was 4.1 for wheat grain yield. The CRM value appeared to be close agreement; it was 2.6. In the same trend, d-State value was 0.92 for grain yield.

Table (8): The simulated \& observed wheat grain yield for both seasons, RMSE, CRM and d-State evaluation coincidence.

\begin{tabular}{|c|c|c|c|c|}
\hline \multirow[t]{2}{*}{ Treatment } & \multicolumn{2}{|c|}{$\begin{array}{c}2016 / 17 \\
\text { Grain yield (kg/feddan) } \\
\end{array}$} & \multicolumn{2}{|c|}{$\begin{array}{c}2017 / 18 \\
\text { Grain yield (kg/feddan) } \\
\end{array}$} \\
\hline & Simulated & Observed & Simulated & Observed \\
\hline I1F1 & 1806 & 2270 & 1649 & 1933 \\
\hline I1F2 & 2393 & 2740 & 2077 & 2296 \\
\hline I1F3 & 2981 & 3260 & 2427 & 2400 \\
\hline I1F4 & 3402 & 3460 & 2560 & 2567 \\
\hline I1F5 & 3407 & 3320 & 2483 & 2474 \\
\hline $\mathrm{I} 2 \mathrm{~F} 1$ & 1818 & 2320 & 1643 & 1891 \\
\hline $\mathrm{I} 2 \mathrm{~F} 2$ & 2397 & 2770 & 2054 & 2277 \\
\hline $\mathrm{I} 2 \mathrm{~F} 3$ & 2982 & 3320 & 2422 & 2369 \\
\hline $\mathrm{I} 2 \mathrm{~F} 4$ & 3413 & 3530 & 2524 & 2403 \\
\hline I2F5 & 3353 & 3320 & 2475 & 2301 \\
\hline I3F1 & 1688 & 2210 & 1625 & 1767 \\
\hline $\mathrm{I} 3 \mathrm{~F} 2$ & 2116 & 2590 & 2047 & 2133 \\
\hline I3F3 & 2631 & 2940 & 2320 & 2267 \\
\hline I3F4 & 3028 & 3350 & 2391 & 2300 \\
\hline I3F5 & 2916 & 3210 & 2244 & 2130 \\
\hline RRMSE & \multicolumn{2}{|c|}{6.6} & \multicolumn{2}{|c|}{3.9} \\
\hline CRM & \multicolumn{2}{|c|}{9.6} & \multicolumn{2}{|c|}{1.7} \\
\hline $\mathrm{d}$ & \multicolumn{2}{|c|}{0.90} & \multicolumn{2}{|c|}{0.92} \\
\hline
\end{tabular}


The results confirmed that the model was able to predict wheat grain yield under the studied treatments, at Upper Egypt condition. These results were recommended by Choudhury et al. (2018) under Bangladesh environment, Kumar et al. (2017) under Western Zone of Haryana, and Abou El-Enin et al. (2016) who examined CERES-Wheat model under Egypt condition, and they found a very good capability of the model for predicting grain yield at different locations.

\section{Conclusion}

In this study, after successful calibration and validation of the model, simulated wheat yields (Misr2 cultivar) from DSSAT-Ceres wheat were evaluated with observed wheat yields grown at the two studied seasons, 2016/17 and 2017/18. The model performance was good under different irrigation and nitrogen application management for Upper Egypt condition. Thus, analysis of the impacts of different management and climate change could be applied.

\section{References}

Abou El-Enin, M. M., Abo-Remaila, S. I. and Mahmoud, A. S. (2016), "Application and evaluation of DSSAT v.4.6.1 program for simulation of wheat and soybean yields in Egypt", Journal of Basic and Environmental Sciences, Vol. 3, pp. 85-97.
Ahmed, B., Ishag, A. A. Hassan, M. K. Ahmed, M. O. (2017), "Response of two wheat cultivars (Triticum aestivum $L$ ) to amended nitrogen fertilizer on yield and grain quality in Halfa Elgadidah Area", MOJ Biology and Medicine, Vol.1 No. 5, pp. 133-136.

Arora, V. and Gajri, R. (1998), "Evaluation of a crop growth-water balance model for analyzing wheat responses to climate and water limited environment", Field Crops Research, Vol. 59, pp.213-224.

Brower, J. E. and Zar, J. H. (1984), Field and laboratory methods for general ecology, Wm. C. Brown Publishers, Dubuque, Iowa, USA, pp. 226.

Calderini, D. Abeledo, L. Savin, R. and Slafer, G. A. (1999), "Effect of temperature and carpel size during pre-anthesis on potential grain weight in wheat", The Journal of Agricultural Science, Vol. 132 No. 04, pp. 453-459.

Chandra, K. (2005), Production and quality control of organic inputs, Regional Director, Regional Centre of Organic Farming, Hebbal, Banglaore, India.

Choudhury, A. K. Ishtiaque, S. Sen, R. Jahan, M. A. H. S. Akhter, S. Ahmed, F. Biswas, J. C. Manirruzaman, M. Hossain, M. B. MuinnuddinMiah, M. Rahman, M. M. Zahan, T. Khan, A. S. M. M. R. and Kalra, N. (2018), "Calibration and validation of DSSAT model for 
simulating wheat yield in Bangladesh", Haya: The Saudi Journal of Life Sciences, Vol. 3 No. 4, pp. 356-364.

El-Marsafawy, S. M. (2000), Scheduling irrigation of wheat crop under different phosphorus fertilizer application times in Middle Egypt, Proceedings of the $5^{\text {th }}$ Conference on Meteorology \& Sustainable Development, pp. 182-195.

El-Sayed, M. M. (2012), Integrating soil moisture with nitrogen management for crop production and environmental protection, Ph.D. Thesis, Faculty of Agriculture, Assiut University, Assiut, Egypt.

FAO. (2005), Fertilizer use by crop in Egypt, available at: http://www.fao.org /3/y5863e /y5863e00.htm\#Contents.

Farhad, W., Cheema, M. A., Saleem, M. F., Radovich, T., Abbas, F., Hammad, H. M. and Wahid, M. A. (2013), "Yield and quality response of maize hybrids to composted poultry manure at three irrigation levels", International Journal of Agriculture and Biology, Vol. 15 No. 2, pp. 181-190.

Feller, C., (1995), Organic matter in tropical soils with 1:1-type clay, Research of functional organic compartments, A particle-size approach, Ph.D. Thesis, Travaux University, France.

FAO (1980), Soil and plant testing as a basis of fertilizer recommendations, FAO Soils, Bulletin No. 38/2, Rome, Italy.

FAO (2008), Fertilizer and Plant Nutrition, Bulleting 19, FAO, Rome, Italy.

Gomaa, M. A. Radwan, F. I. Rehab, I. F. and Mabrouk, W. S. (2015), "Response of bread wheat to organic and nitrogen fertilization", Middle East Journal of Agriculture Research, Vol.4 No. 4, pp. 712-716.

Halepyati, A. S. (2001), "Influence of irrigation and nitrogen levels on growth and yield of wheat", Karnataka Journal of Agricultural Sciences, Vol. 14 No. 2, pp. 449450.

Hoogenboom, G., Jones, J. W., Wilkens, P. W., Porter, C. H., Batchelor, W. D., Hunt, L. A., Boote, K. J., Singh, U., Uryasev, O., Bowen, W. T., Gijsman, A., du Toit, A., White, J. W., and Tsuji, G. Y. (2004), Decision support system for agrotechnology transfer Version 4.0. [CD-ROM], University of Hawaii, Honolulu, Hawaii, USA.

Hoogenboom, G., Jones, J. W., Wilkens, P. W., BootePorter, C. H., Hunt, L. A., (2012), Decision Support System for Agro technology Transfer (DSSAT) Version 4.5., University of Hawaii, Honolulu, Hawaii, USA.

Jala-Abadi, A. L., Siadat, S. A., Bakhsandeh, A. M., Fathi, G. and Saied, K. H. A. (2012), "Effect 
oforganic and inorganic fertilizers on yield and yield components in wheat ( $T$. aestivum and $T$. durum) genotypes", Advances in Environmental Biology, Vol. 6 No. 2, pp. 756-762.

Jamieson, P. D., Porter, J. R. and Wilson, D. R. (1991), "A test of the computer simulation model ARCWHEAT on wheat crops grown in New Zealand", Field Crops Research, Vol. 27, pp 337-350.

Jones, J. W., Hoogenboom, G., Porter, C. H., Boote, K. J., Batchelor, W. D., Hunt, L. A., Wilkens P. W, Singh U Gijsman, A. J., Ritchie J. T. (2003), "The DSSAT cropping system model", European Journal of Agronomy, Vol. 18 No. 3-4, pp. 235-265,

Jones, M. R. (2013), Incorporating the canegro sugarcane model into the DSSAT 44 cropping system model framework, M.Sc. Thesis, University of KwaZulu-Natal, Pietermaritzburg, South Africa.

Khalil, F. A., H. Farag, G. El-Afandi, and Ouda, S. A. (2009), Vulnerability and adaptation of wheat to climate change in Middle Egypt, Proceeding of the $13^{\text {th }}$ International Conference on Water Technology, Egypt, pp. $12-15$

Koushal, S., Sharma, A. K. and Singh, A. (2011), "Yield performance, economics and soil fertility through direct and residual effects of organic and inorganic sources of nitrogen as substitute to chemical fertilizer in rice-wheat cropping system", Research Journal of Agricultural Sciences, Vol. 43 No. 3, pp. 762 774.

Kumar, M., Pannu, R. K., Singh, R. J., Singh, B., Dhaka A. K. and Rajeev (2017), "Prediction of growth and yield of late sown Wheat Using DSSAT (v4.5) model under Western Zone of Haryana", International Journal of Current Microbiology and Applied Sciences, Vol. 6 No. 3, pp. 1687-1696.

Loague, K. and Green, R. E. (1991), "Statistical and graphical methods for evaluating solute transport models: Overview and application", Journal of Contaminant Hydrology, Vol. 7, pp. 51-73.

Mohamed, K. A. and Abdel-Rahman, M. A. M. (2015), "Effect of different sources of nitrogen fertilizers combined with vermiculite on productivity of wheat and availability of nitrogen in sandy soil in Egypt", American Journal of Plant Nutrition and Fertilization Technology, Vol. 5, pp. 50-60.

Namait Allah, Y. O., Sadik, M. K., Abd El-Haleem, A. M. A., Eid, H. M. and Salem, H. M. (2008), "Effect of irrigation scheduling and applied nitrogen level on water relation, yield and yield components for wheat crop grown in Middle Egypt (Giza region)", Journal of Biological Chemistry and Environmental Science, Vol. 3 No. 4, pp. 81-102. 
Nelson, D. W. and Sommers, L. E. (1996), "Total carbon, organic carbon, and organic matter", In: Methods of soil analysis, Part 2, $2^{\text {nd }}$ ed., Page, A. L. et al. (eds.), American Society of Agronomy Inc., Madison, USA, pp. 961-1010.

Nissen, O. (1989), MSTAT-C: A microcomputer program for the design, management and analysis of agronomic research experiments, Michigan State University, East Lansing, Michigan, USA.

Noreen, F., Noreen, S. (2012), "Effect of different fertilizers on yield of wheat", International Journal of Science and Research (IJSR), Vol. 3 No. 11, pp. 1596-1599.

Page, A. L., Miller, R. H. and Keeny, D. R. (1982), Methods of Soil Analysis, Part 2, Soil Science Society of America Inc., Madison, Wisconsin, USA.

Piper, C. S. (1966), Soil and plant analysis, Hans Publishers, Bombay, India.

Pushpavalli, R., Zaman-Allah, M., Turner, N. C., Baddam, R., Rao, M. V. and Vadezm, V. (2014), "Higher flower and seed number leads to higher yield underwater stress conditions imposed during reproduction in chickpea", Functional Plant Biology, Vol 42, pp 162-174.

Rao, S. S., Regar, P. L., Tanwar, S. P. S. and Singh, Y. V. (2013), "Wheat yield response to line source sprinkler irrigation and soil management practices on mediumtextured shallow soils of arid environment", Irrigation Science, Vol. 31 No. 11, pp. 85-97.

Rayan, A. A., El-Marsafawy, S. M., Ainer, N. G. and Soliman, S. E. (2000), "Schedule irrigation of wheat crop in Upper Egypt under some sowing dates", Egyptian Journal of Applied Sciences, Vol. 15 No. 1, pp. 10-23.

Rehman, S., Khalil, S. K., Rehman, A. and Saljoqi, A. U. R. (2008), "Organic and inorganic fertilizers increase wheat yield components and biomass under rainfed condition", Sarhad Journal of Agriculture, Vol. 24 No. 1, pp. 1218.

Rowell, D. L. (1994), Soil science: method and applications, Longman publishers, Singapore, pp. 350.

Sánchez, B., Rasmussen, A. and Porter, J. R. (2013), "Temperatures and the growth and development of maize and rice: A Review", Global Change Biology, Vol. 20, pp. 408-417.

Sehgal, A., Sita, K., Siddique, K. H., Kumar, R., Bhogireddy, S., Varshney, R. K., Hanumantharao, B., Nair, R. M., Prasad, P. V. and Nayyar, H. (2018), "Drought or/and heat-stress effects on seed filling in food crops: Impacts on functional biochemistry, seed yields, and nutritional quality", Frontiers in 
Plant Science, Vol. 9 Article ID: 1705.

Sestak, C. B., Catsky, J. and Jarris, P. G. (1971), "Plant Synthesis", In Production Manual of Methods, Dr. W. Junk Publishers, The Hague, Netherlands, pp. 343-381.

Shah, Z. and Ahmad, M. I. (2006), "Effect of integrated use of farm yard manure and urea on yield and nitrogen uptake of wheat", Journal of Agricultural and Biological Science, Vol.1, No.1, pp. 60-65.

Shah, A. S., Shah, S. M., Mohammad, W., Shafi, M., Nawaz, H., Shehzadi, S. and Amir, M. (2010), "Effect of integrated use of organic and inorganic nitrogen sources on wheat yield", Sarhad Journal of Agriculture, Vol. 26 No. 4, pp. 559563

Singh, R. and Agarwal, S. K. (2001), "Growth and yield of wheat (Triticum aestivum L.) as influenced by levels of farmyard manure and nitrogen", Indian Journal of Agronomy, Vol. 46 No. 3, pp. 462467.

Smajstrla, A. G., Zazueta, F. S., Clark, G. and Pitts, D. J. (2000), Irrigation scheduling with evaporation pans, Vol. 254, Extension Bulletin, Institute of Food and Agricultural Sciences, University of Florida Extension, USA, pp. 11.

Stanhill, G. (2002), "Is the Class A evaporation pan still the most

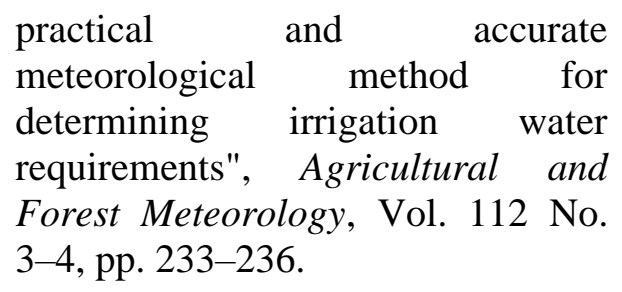

Subhan, Q. U. K., Mansoor, M. and Khan, M. J. (2017), "Effect of organic and inorganic fertilizer on the water use efficiency and yield attributes of wheat under heavy textured soil", Sarhad Journal of Agriculture, Vol. 33 No. 4, pp. 582590.

Xevi, E. L., Gilley, J. and Feyen, J. (1996), "Comparative study of two crop yield simulation models", Agricultural Water Management, Vol. 30, pp. 155-173.

Youssef, M. A., El-Sayed, M. M. and Sadek, I. (2013), "Impact of organic manure, bio-fertilizer and irrigation intervals on wheat growth and grain yield", American-Eurasian Journal of Agricultural \& Environmental Sciences, Vol. 13 No. 11, pp. 1488 1496.

Zia, M. S., Mann, R. A., Aslam, M., Khan, M. A. and Hussain, F. (2000), The role of green manuring in sustaining rice-wheat production, In: Proceedings of Symposium on Integrated Plant Nutrition Management, NDFC, Islamabad, Pakistan, pp. 130-149. 